\title{
BEBAN PENCEMARAN SUMBER LIMBAH DI SUNGAI CODE
}

\author{
Titiek Widyasari \\ Dosen Tetap, Jurusan Teknik Sipil, Fakultas Teknik, Universitas Janabadra \\ Jalan Tentara Rakyat Mataram No. 55 - 57 Yogyakarta 55231 \\ E-mail : titiekwidyasari@gmail.com; myson_jayastu@yahoo.co.id
}

\begin{abstract}
Code river is one of river in Yogyakarta, which own strategic area, where is Code river through urban area that densely populated area. Monitoring was executed by Badan Pengendalian Dampak Lingkungan Daerah (BAPEDALDA) Yogyakarta, it is a river water quality monitoring, it hasn't at waste water resources quality. Therefore, necessary to research about waste water resources quality monitoring at Code river. The study area is located in alongside Code river, from Gondolayu bridge until Mas Suharto bridge, river length thereabouts $2 \mathrm{~km}^{2}$, because the location own strategic area through urban area that densely populated area. Identification waste water resources which wasted to Code river, is 25 location at east side and 41 location at west side. Discharge activity asynchronous. In point $12 \mathrm{~A}$, according to quantity and quality is greatest, it is communal canal from mansions at Kota Baru area that densely populated area and its discharge activity continues. The result research about domestic waste water quantity is $5.44 \mathrm{~L} / \mathrm{s}$. At 66 location waste water resources, BOD parameter less than limit of threshold value, so is still agree with domestic waste water quality standard. But in quantity monitoring is derived that the actual pollution load BOD parameter is 46.83 $\mathrm{kg} /$ day more than maximum pollution load BOD parameter what is licensed, it is $25.80 \mathrm{~kg} / \mathrm{day}$. So waste water resources at study area have polluted Code river. Therefore, effort about pollution control at Code river is necessary quality and quantity monitoring waste water resources incessantly and periodic by the stakeholders in active.
\end{abstract}

Keywords: Domestic waste water, Waste water resources, Code river.

\begin{abstract}
ABSTRAK
Sungai Code merupakan salah satu sungai yang melalui wilayah Daerah Istimewa Yogyakarta (DIY) dan memiliki lokasi straregis, bagian tengah daerah pengaliran sungai Code melintasi daerah perkotaan yang padat penduduk. Pemantauan yang dilaksanakan tersebut merupakan pemantauan kualitas air sungai, belum pada kualitas sumber limbah. Penelitian mengenai pemantauan debit dan kadar BOD sumber limbah yang membebani sungai Code perlu dilakukan. Lokasi penelitian di sepanjang sungai Code dari Jembatan Gondolayu sampai Jembatan Mas Suharto, panjang sungai kurang lebih $2 \mathrm{~km}$, dengan pertimbangan lokasi penelitian melalui wilayah perkotaan. Identifikasi sumber limbah yang membuang ke sungai Code sebanyak 25 lokasi di sisi timur dan 41 lokasi di sisi barat. Aktifitas pembuangan limbah tidak serempak dan tidak semua saluran limbah yang ada di lokasi penelitian melakukan aktifitas pembuangan. Titik 12A merupakan sumber limbah dengan debit dan kadar BOD terbesar serta saluran yang terus menerus mengalir. Titik 12A merupakan saluran komunal yang berasal dari rumah-rumah di kawasan Kota Baru yang cukup padat dan saluran tersebut berfungsi juga sebagai riool kota. Total air limbah domestik pada saat penelitian ini sebesar 5,44 L/detik. Dari 66 lokasi sumber limbah, sebagian besar kadar BOD berada di bawah atau lebih kecil dari nilai ambang batas (NAB) sehingga masih memenuhi baku mutu limbah domestik. Secara pemantauan kuantitas didapat beban pencemaran aktual (BPA) BOD sebesar 46,83 kg/hari lebih besar dibandingkan dengan beban pencemaran maksimum yang diizinkan (BPM) BOD sebesar 25,80 $\mathrm{kg}$ /hari, sehingga dapat disimpulkan beban pencemaran dari sumber limbah pada lokasi penelitian mencemari sungai Code. Upaya pengendalian pencemaran di sungai Code adalah perlu pemantauan kualitas dan kuantitas sumber limbah secara periodik dan berkelanjutan, serta perlu mengikutsertakan masyarakat, swasta, industri dan pemerintah untuk terlibat aktif dalam pengelolaan sungai.
\end{abstract}

Kata Kunci: Limbah domestik, Sumber limbah, Sungai Code. 


\section{PENDAHULUAN}

Sungai sebagai badan air yang bersifat terbuka yang memiliki banyak fungsi yang memerlukan usaha secara terus menerus dalam pengelolaan, baik pada sungai itu sendiri maupun pada daerah tangkapan sungai. Sungai juga merupakan sumber daya alam yang sangat penting bagi kehidupan manusia dan menjaga fungsi keseimbangan alam. Berkaitan dengan kebutuhan air yang cenderung meningkat, maka perlu membuat langkah nyata dalam menjaga kelestarian sumber daya air sungai.

Sungai Code merupakan salah satu sungai yang melalui wilayah Daerah Istimewa Yogyakarta (DIY) dan memiliki lokasi straregis, karena daerah aliran sungai (DAS) dan alur sungai melewati Kabupaten Sleman, Kota Yogyakarta dan Kabupaten Bantul. Bagian tengah daerah pengaliran sungai Code melintasi daerah perkotaan yang padat penduduk. Pertambahan jumlah penduduk, maka semakin sempit lahan pemukiman dan semakin sempit pula lahan untuk sarana pembuangan air limbah seperti septictank yang memenuhi syarat. Tanpa pengolahan yang baik, tentunya limbah ini akan terakumulasi dalam media lingkungan dan berakibat mencemari lingkungan. Air limbah akan mencemari badan air seperti sungai, bila air limbah dibuang langsung ke badan air. Tahun 2003, Departemen Kimpraswil menyatakan bahwa hampir 60\% rumah tangga di Pulau Jawa langsung membuang limbahnya ke badan air terdekat (got atau sungai) tidak terkecuali sungai Code [Fiona, 2006]. Pengujian laboratorium beberapa instansi terkait menunjukan bahwa kualitas air di perkotaan Yogyakarta sudah sangat memprihatinkan dan tidak layak untuk dikonsumsi. Sungai dengan kualitas air terburuk adalah sungai Code [Feybe, 2006]. Bagi warga yang mempunyai we pribadi limbah cair dibuang langsung dari wc dan kamar mandi melalui pipa-pipa ke sungai dan bagi warga yang tidak mempunyai wc, sungai adalah pilihan favorit untuk membuang hajat [Pieter, 2007].

Berdasarkan uraian di atas maka perlu dilakukan penelitian mengenai pemantauan secara kuantitas yaitu debit dan secara kualitas yaitu besar kadar Biochemical Oxygen Demand $(B O D)$ limbah yang membebani sungai Code. Penelitian ini dilakukan dengan tujuan untuk mengetahui kondisi beban pencemaran sumber limbah yang membuang limbahnya langsung ke sungai Code.

\section{KAJIAN KUALITAS AIR SUNGAI CODE}

Sejalan dengan meningkatnya pertumbuhan industri dan perkembangan jumlah penduduk di DIY, maka kuantitas limbah semakin meningkat yang apabila dibuang langsung ke sungai akan menyebabkan pencemaran lingkungan. Adanya kencederungan masyarakat dan sektor industri membuang limbah ke sungai semakin meningkat dari tahun ke tahun. Hal 
tersebut tentu sangat mengkuatirkan mengingat dampak untuk masa mendatang tidaklah mudah dan murah untuk diatasi. Masalah pencemaran air pada saat ini sudah menyentuh berbagai kepentingan, yakni kepentingan manusia, hewan, tumbuhan dan organisme lain, karena dalam kehidupan selalu membutuhkan air untuk berlangsungnya segala aktifitas biologis, dimana air yang diperlukan adalah air yang kualitasnya memenuhi syarat baku mutu sesuai peruntukkannya.

Pemerintah Daerah Propinsi DIY dalam upaya melaksanakan pengendalian pencemaran air pada badan air dan mendukung Program Kali Bersih perlu melakukan pemantauan secara periodik terhadap kualitas air sungai Code untuk mengetahui sedini mungkin tingkat pencemaran yang terjadi. Pemerintah Propinsi DIY melalui Badan Pengendalian Dampak Lingkungan Daerah (BAPEDALDA) Propinsi DIY pada Tahun Anggaran 2005 dan 2006 melakukan pemantauan kualitas air badan air dengan salah satu sasaran yaitu sungai Code [Anonim, 2005 dan 2006].

Pemantauan kualitas air sungai Code dilakukan 4 kali dalam setahun. Pada tahun 2005 dilaksanakan di bulan April, Juni, Agustus dan Oktober. Sedangkan pada tahun 2006 dilaksanakan di bulan Februari, Mei, September dan Desember. Salah satu okasi pengambilan sampel dari 9 lokasi adalah pada tahun 2005 di jembatan Gondolayu dan jembatan Keparakan, sedangkan pada tahun 2006 di jembatan Gondolayu dan jembatan Sayidan.

Dari pemantauan kualitas air sungai Code pada tahun 2005 dan tahun 2006 diperoleh hasil seperti Gambar 1 sebagai berikut.

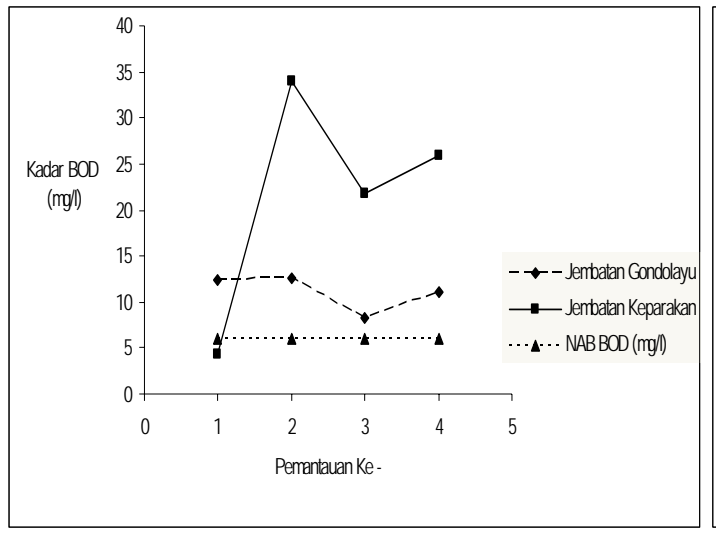

(a) Tahun 2005

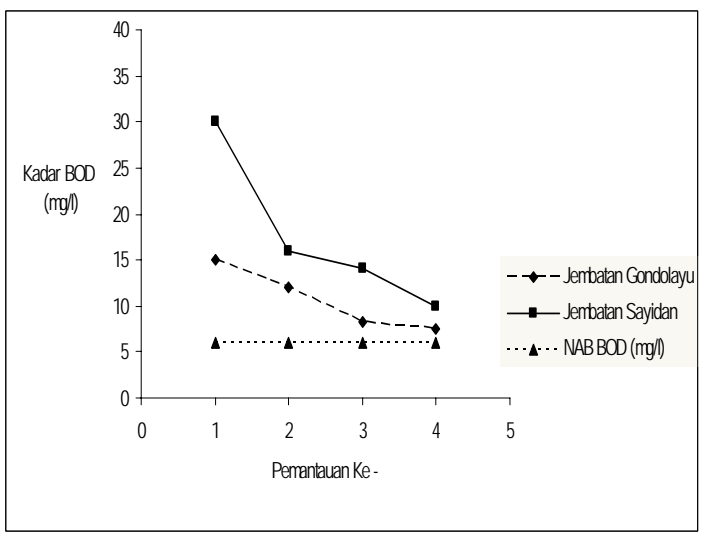

(b) Tahun 2006

Gambar 1. Pemantauan Kadar BOD Air Sungai Code di Jembatan Gondolayu dan Jembatan Keparakan (Sumber: Anonim, 2005 dan 2006). 
Dilihat dari Gambar 1 pada tahun 2005 dan tahu 2006 diperoleh kondisi air sungai Code di titik pemantauan mengalami peningkatan kadar BOD dan berada di atas Nilai Ambang Batas (NAB) BOD untuk kelas air sungai masuk kelas Tiga dengan NAB BOD sebesar 6 mg/l [Anonim, 2001]. Dimana klasifikasi mutu air dalam Peraturan Gubernur bahwa kelas Tiga adalah air yang peruntukannya dapat digunakan untuk pembudidayaan ikan air tawar, peternakan, air untuk mengairi pertanaman, dan atau peruntukan lain yang mempersyaratkan mutu air yang sama dengan kegunaan tersebut [Anonim, 2007]. Pemantauan yang dilaksanakan oleh BAPEDALDA Propinsi DIY merupakan pemantauan kualitas air sungai, belum pada kualitas sumber limbah yang masuk ke sungai.

\section{PENCEMARAN SUNGAI}

\subsection{Limbah Domestik}

Limbah cair menurut sumbernya terdiri limbah dari kegiatan domestik (rumah tangga) dan kegiatan industri. Air limbah domestik adalah air limbah yang berasal dari usaha dan atau kegiatan pemukiman (real estate), rumah makan (restauran), perkantoran, perniagaan, apartemen dan asrama (Anonim, 2003). Limbah domestik adalah hasil buangan yang tidak terpakai dari kegiatan manusia sehari-hari seperti buangan cucian, mandi, dan air kotor (tinja/black water). Sumber limbah domestik meliputi kegiatan perumahan, perkantoran, perhotelan, pertokoan, rumah sakit kecuali yang berasal dari laboratorium yang berupa limbah B3 (Bahan Beracun dan Berbahaya), usaha laundry, usaha rumah makan dan lain-lain.

Baku mutu limbah domestik pada Lampiran Keputusan Menteri Negara Lingkungan Hidup dirinci pada Tabel 1 [Anonim, 2003].

Tabel 1. Baku mutu limbah domestik.

\begin{tabular}{lcc}
\hline \multicolumn{1}{c}{ Parameter } & Satuan & Kadar Maksimum \\
\hline \hline $\mathrm{pH}$ & - & $6-9$ \\
$\mathrm{BOD}$ & $\mathrm{mg} / \mathrm{l}$ & 100 \\
$\mathrm{TSS}$ & $\mathrm{mg} / \mathrm{l}$ & 100 \\
Minyak dan lemak & $\mathrm{mg} / \mathrm{l}$ & 10 \\
\hline
\end{tabular}

Sumber: Anonim, 2003

Beban Pencemaran Sumber Limbah Di Sungai Code 
BOD adalah banyaknya oksigen yang dibutuhkan oleh mikrobia untuk melakukan perombakan bahan organik dalam suatu perairan. Air yang bersih mengandung mikroba lebih sedikit dibanding air yang tercemar oleh bahan buangan, mikroba yang memerlukan oksigen untuk memecah bahan organik disebut bakteri aerobik. Apabila suatu badan air dicemari oleh zat-zat organik mikroba dapat menghabiskan oksigen yang terlarut dalam air (DO) untuk perombakan zat organik tersebut dan akan terjadi proses perombakan secara anaerob (tanpa menggunakan $\mathrm{O}_{2}$ ) yang dapat mengakibatkan kematian untuk makluk hidup dalam air sehingga menimbulkan bau busuk yang berakibat pada pencemaran udara. Pengujian BOD yang dapat diterima adalah pengukuran jumlah oksigen yang akan dihabiskan dalam waktu lima hari oleh organisme pengurai aerobik dalam suatu volume pada suhu $20^{\circ} \mathrm{C}$, hasilnya dinyatakan dalam ppm (part per milion) atau mg/liter. Air buangan domestik yang tidak mengandung limbah industri mempunyai nilai BOD kira-kira 200 ppm, ini berarti bahwa 200 ppm oksigen akan dihabiskan oleh contoh limbah sebanyak satu liter dalam waktu lima hari pada suhu $20^{\circ} \mathrm{C}$.

\subsection{Beban Pencemaran Limbah Cair}

Perhitungan beban pencemaran maksimum untuk menentukan mutu limbah cair merujuk pada Keputusan Menteri Negara Lingkungan Hidup No: 03/MENLH/1998 tanggal 15 Januari 1998. Penerapan baku mutu limbah cair pada pembuangan limbah cair melalui penetapan beban pencemaran maksimum seperti Tabel 2 berdasarkan pada jumlah unsur pencemar yang terkandung dalam air limbah cair.

Tabel 2. Baku mutu limbah cair Kawasan Industri dan Hotel.

\begin{tabular}{ccc}
\hline \multirow{2}{*}{ PARAMETER } & \multicolumn{2}{c}{ KADAR MAKSIMUM $(\mathrm{mg} / \mathrm{L})$} \\
\cline { 2 - 3 } & KAWASAN INDUSTRI & KAWASAN HOTEL \\
\hline \hline BOD $_{5}$ & 50 & 30 \\
COD & 100 & 100 \\
TSS & 200 & 50 \\
pH & $6,0-9,0$ \\
\hline \multicolumn{3}{c}{ Debit Limbah cair Maksimum } \\
\end{tabular}

Sumber: Anonim, 1995 dan Anonim, 1998a

Rumus perhitungan beban pencemaran maksimum yang diizinkan dan beban pencemaran sebenarnya adalah sebagai berikut [Anonim, 1998b]: 


$$
\mathrm{BPM}=(\mathrm{Cm}) \mathrm{j} \times \mathrm{Dm} \times \mathrm{A} \times \mathrm{f}
$$

dimana:

BPM = beban pencemar maksimum yang diperbolehkan $(\mathrm{kg} / \mathrm{hari})$,

$(\mathrm{Cm}) \mathrm{j}=$ kadar maksimum parameter pada Tabel $1(\mathrm{mg} / \mathrm{L})$,

$\mathrm{Dm}=$ debit limbah cair seperti Tabel 1 sebesar $1 \mathrm{~L} /$ detik/ha,

A = luas lahan kawasan yang terpakai (ha),

$\mathrm{f} \quad=$ faktor konversi sebesar 0,086 .

$\mathrm{BPA}=(\mathrm{CA}) \mathrm{j} \times \mathrm{DA} \times \mathrm{f}$

dimana:

BPA = beban pencemar sebenarnya (aktual) yang dibuang $(\mathrm{kg} / \mathrm{hari})$,

$(\mathrm{CA}) \mathrm{j} \quad=$ kadar sebenarnya parameter pada Tabel $2(\mathrm{mg} / \mathrm{L})$,

DA = debit limbah cair sebenarnya (L/detik).

Evaluasi penilaian beban pencemaran adalah BPA tidak boleh melebihi BPM. Bila BPA lebih besar dari BPM maka kawasan terpakai tercemar oleh sumber limbah. Sedangkan bila BPA lebih kecil dari BPM maka kawasan terpakai tidak tercemar oleh sumber limbah.

\section{METODE PENELITIAN}

\subsection{Lokasi Penelitian}

Lokasi penelitian di sepanjang sungai Code dari Jembatan Gondolayu sampai Jembatan Mas Suharto, panjang sungai kurang lebih $2 \mathrm{~km}$. Dasar pertimbangan pemilihan lokasi penelitian adalah sungai melalui wilayah perkotaan Kota Yogyakarta, dimana kondisi sekitar sungai berupa pemukiman penduduk yang padat, ada kegiatan industri, pertokoan, perkantoran, usaha rumah makan, perhotelan, usaha laundry dan lain-lain. Penelitian tidak dilakukan sepanjang Sungai Code yang melintasi Kota Yogyakarta, karena terkait dengan keterbatasan dana dan waktu.

\subsection{Tahapan Penelitian}

Identifikasi sumber limbah dengan cara menyusur sungai baik sisi barat maupun sisi timur (kanan dan kiri) untuk identifikasi sumber limbah yang membuang ke sungai Code dengan cara melihat saluran limbah yang berada di tebing atau di bantaran sungai. Saluran yang diamati dan diidentifikasi adalah saluran yang masih digunakan atau air limbah mengalir secara terus menerus. Indentifikasi meliputi pengukuran posisi sumber limbah 
(saluran dari rumah tangga/riool kota/industri) dengan Global Positioning System (GPS), menandai lokasi/saluran, mencatat kondisi saluran dan mencatat nama daerah administrasi. Dokumentasi berupa foto ditiap saluran pembuangan limbah ke sungai Code. Plotting data GPS ke peta sungai Code.

Dari peta posisi atau lokasi sumber limbah yang diperoleh dilakukan pengukuran debit air limbah ditiap lokasi, pengambilan sampel dan pemeriksaan kadar BOD di laboratorium.

\section{HASIL PENELITIAN}

\subsection{Hasil Identifikasi Lokasi Sumber Limbah}

Penelitian ini terdiri dari 2 kegiatan yaitu kegiatan 1 menyusur sungai, kegiatan 2 pengukuran debit dan pengambilan sampel. Kegiatan 1 dilaksanakan pada tanggal 5 Mei 2008, sedangkan kegiatan 2 dilaksanakan pada tanggal 22 Mei 2008. Hasil penelitian mengidentifikasi sumber limbah yang dibuang ke sungai Code sebanyak 25 lokasi di sisi timur dan 41 lokasi di sisi barat sepanjang lokasi penelitian dari Jembatan Gondolayu sampai Jembatan Mas Suharto.

\subsection{Analisis Debit Sumber Limbah}

Lokasi sumber limbah yang diperoleh pada kegiatan 1, kemudian dilakukan pengukuran debit dan pengambilan sampel. Kegiatan pengukuran debit dilakukan pada pagi hari jam 09.00 sampai dengan 11.00 wib. Sumber limbah di sisi timur ada 12 atau $48 \%$ saluran yang mengalir (ada aktifitas pembuangan limbah) dengan total debit sebesar 1.888 $\mathrm{ml} / \mathrm{s} \approx 1,9$ 1/s dan rata-rata $76 \mathrm{ml} / \mathrm{s}$, sedangkan aliran terbesar di titik $12 \mathrm{~A}$ sebesar $500 \mathrm{ml} / \mathrm{s}$. Sumber limbah di sisi barat ada 28 atau $68 \%$ ada aktifitas pembuangan limbah dengan total debit sebesar $2.149 \mathrm{ml} / \mathrm{s} \approx 2,15 \mathrm{l} / \mathrm{s}$ dan rata-rata $86 \mathrm{ml} / \mathrm{s}$, sedangkan aliran terbesar di 18B sebesar $500 \mathrm{ml} / \mathrm{s}$. Adapun jumlah total air limbah domestik yang dibuang ke sungai Code pada penelitian ini sebesar $4,05 \mathrm{l} / \mathrm{s}$.

Aktifitas pembuangan limbah tidak serempak. Jadi tidak semua saluran limbah yang ada di lokasi penelitian melakukan aktifitas pembuangan. Sumber limbah berasal dari rumah yang berada di tepi sungai, dari kamar mandi umum yang dibangun di tepi sungai, dari saluran limbah komunal dari rumah-rumah di bantaran sungai dan dari saluran riool kota. Saluran limbah dari rumah penduduk dan kamar mandi umum untuk aktifitas pembuangan tidak kontinu tergantung kegiatan penduduk. Saluran komunal dan saluran riool kota untuk aktifitas pembuangan kontinu atau terus menerus. Dari kondisi tersebut maka pembebanan sumber limbah ke sungai Code relatif tidak tetap. Hal tersebut disebabkan oleh pembuangan 
limbah domestik didasarkan pada kegiatan atau aktifitas penduduk/manusia baik mandi, cuci dan kakus (MCK).

\subsection{Analisis Kadar BOD}

Pemeriksaan sampel air limbah di Laboratorium Balai Besar Teknik Kesehatan Lingkungan dan Pemberatasan Penyakit Menular (BBTKLPPM) Yogyakarta, Departemen Kesehatan Republik Indonesia, Direktorat Jenderal Pengendalian Penyakit dan Penyehatan Lingkungan. Metode pemeriksaan yang dilakukan menggunakan metode uji APHA 2005 Section 5210 B, Section 4500-OG. NAB atau kadar maksimum BOD untuk baku mutu limbah domestik pada Tabel 1 sebesar $100 \mathrm{mg} / \mathrm{l}$ [Anonim, 2003]. Gambar 2 terlihat bahwa dari 66 lokasi sumber limbah kadar BOD berada di bawah atau lebih kecil dari NAB BOD. Sebagian besar atau sebesar $92 \%$ kualitas limbah yang dibuang ke sungai Code pada lokasi penelitian ini masih memenuhi baku mutu limbah domestik, hanya sekitar $8 \%$ mendekati NAB BOD yaitu titik 12A (100,1 mg/l), 24A (96,1 mg/l), 35B (94,1 mg/l), 37B (88,1 mg/l) dan 39B $(80,1 \mathrm{mg} / \mathrm{l})$.

Sumber limbah di titik 12A perlu diperhatikan, karena kadar BOD yang paling besar, debit yang paling besar dan kondisi aliran yang terus menerus mengalir. Titik 12 A merupakan sumber limbah dari saluran komunal yang berasal dari rumah-rumah di kawasan Kota Baru yang cukup padat dan saluran tersebut berfungsi juga sebagai riool kota.

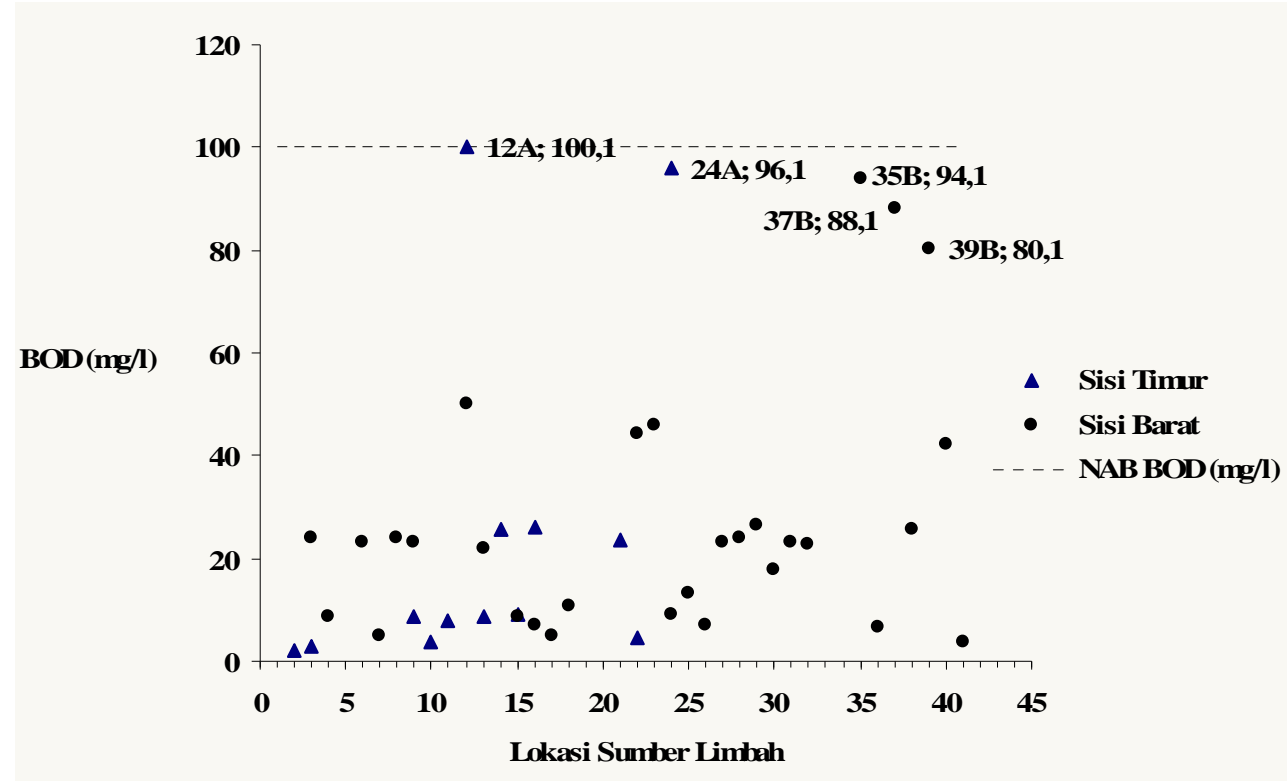

Gambar 2. Kadar BOD (mg/l) di sisi timur dan sisi barat. 


\subsection{Analisis Beban Pencemaran}

Hasil penelitian menunjukkan bahwakadar BOD maksimum aktual (CA) BOD $_{\text {sebesar }}$ 100,1 mg/L dengan total debit aliran (DA) sebesar 5,44 L/detik. Berdasarkan Persamaan 2 dapat diketahui beban pencemar aktual (BPA) sebesar 46,83 kg/hari.

Beban pencemaran maksimum yang diizinkan (BPM) dihitung dengan menggunakan Persamaan 1, dimana kadar BOD maksimum $(\mathrm{Cm})_{\text {BOD }}$ sesuai Tabel 2 untuk kawasan Hotel (dengan asumsi kondisi lokasi penelitian terdapat banyak kegiatan perhotelan dan pemukiman) sebesar $30 \mathrm{mg} / \mathrm{L}$ dan debit limbah cair maksimum (Dm) sebesar $1 \mathrm{~L} /$ detik/ha lahan kawasan terpakai. Luasan lahan kawasan yang terpakai untuk penelitian ini diperkirakan sebesar 10 ha. Besar BPM adalah 25,80 kg/hari

BPA sebesar 46,83 kg/hari lebih besar dibandingkan dengan BPM sebesar 25,80 $\mathrm{kg} /$ hari dapat disimpulkan bahwa beban pencemaran pada lokasi penelitian yaitu sumber limbah di sungai Code dari jembatan Sudirman sampai dengan jembatan Mas Suharto untuk kadar BOD mencemari sungai Code.

Dilihat dari baku mutu limbah domestik (Anonim, 2003) menunjukkan kualitas limbah dari sumber limbah yang diamati pada penelitian ini tidak melebihi NAB, yang berarti secara kualitas limbah tidak mencemari. Bila dilihat dari mutu limbah cair merujuk pada Keputusan Menteri Negara Lingkungan Hidup No: 03/MENLH/1998 [Anonim, 1998] tentang penetapan beban pencemaran diperoleh hasil beban limbah dari sumber limbah pada lokasi penelitian mencemari sungai Code. Hal tersebut menujukkan bahwa kualitas limbah yang dibuang ke sungai Code relatif kecil, namun kuantitas (jumlah) limbah yang dibuang akan membebani sungai sebagai media pembuangan. Upaya pemantauan sumber limbah yang diperlukan adalah pemantauan kualitas, kuantitas dan intensitas, sehingga sumber limbah dikatakan mencemari bila melebihi dari sisi kualitas, kuantitas dan intensitas.

\section{KESIMPULAN DAN SARAN}

Berdasarkan hasil pemantauan dalam penelitian ini, maka dapat diambil kesimpulan sebagai berikut:

1. Identifikasi sumber limbah yang membuang ke sungai Code sepanjang lokasi penelitian dari jembatan Sudirman sampai jembatan Mas Suharto sebanyak 25 lokasi di sisi timur dengan kondisi mengalir sebesar 12 saluran atau 48\% dan 41 lokasi di sisi barat dengan kondisi mengalir sebesar 28 saluran atau $68 \%$.

2. Titik $12 \mathrm{~A}$ merupakan sumber limbah dengan debit dan kadar BOD terbesar serta saluran yang terus menerus mengalir. Hal tersebut disebabkan oleh titik 12A merupakan saluran 
komunal yang berasal dari rumah-rumah di kawasan Kota Baru yang cukup padat dan saluran tersebut berfungsi juga sebagai riool kota.

3. Kadar BOD di 66 lokasi sumber limbah berada di bawah atau lebih kecil dari NAB BOD yaitu $100 \mathrm{mg} / \mathrm{L}$ [Anonim, 2003], sehingga masih memenuhi baku mutu limbah domestik.

4. BPA sebesar $46,83 \mathrm{~kg} / \mathrm{hari}$ lebih besar dibandingkan dengan BPM sebesar 25,80 kg/hari dapat disimpulkan bahwa beban pencemaran pada lokasi penelitian yaitu sumber limbah di sungai Code dari jembatan Sudirman sampai dengan jembatan Mas Suharto untuk kadar BOD mencemari sungai Code.

5. Kualitas limbah yang dibuang ke sungai Code relatif kecil, namun kuantitas (jumlah) limbah yang dibuang akan membebani sungai sebagai media pembuangan.

Upaya pengendalian pencemaran khususnya sungai Code adalah perlu pemantauan kualitas sumber limbah secara periodik dan berkelanjutan, yang mengikutsertakan masyarakat, swasta, industri dan pemerintah untuk terlibat aktif di dalam pemantauan sumber limbah dan pengelolaan kualitas sungai sebagai sumber daya air. Penelitian ini dapat dilanjutkan dengan meneliti sumber limbah sungai Code di wilayah perkotaan yang mencakup sungai Code dari Ring Road Utara sampai dengan Ring Road Selatan.

\section{UCAPAN TERIMA KASIH}

Penelitian ini dibiayai oleh Direktorat Jendral Pendidikan Tinggi, Departemen Pendidikan Nasional dalam Hibah Penelitian Dosen Tahun 2008, dan telah diseminarkan pada Desiminasi Penelitian Dosen Muda Tahun 2008 oleh Lembaga Penelitian, Penjaminan Mutu dan Pengabdian kepada Masyarakat (LP3M) Universitas Janabadra Yogyakarta tanggal 16 April 2009.

\section{DAFTAR PUSTAKA}

1. Anonim. (1995). Keputusan Menteri Negara Lingkungan Hidup No. 52 Tahun1995 Tentang : Baku Mutu Limbah Cair Bagi Kegiatan Hotel, Republik Indonesia, Lampiran B.

2. Anonim. (1998a). Keputusan Menteri Negara Lingkungan Hidup No. 3 Tahun1998 Tentang : Baku Mutu Limbah Cair Bagi Kawasan Industri, Republik Indonesia, Lampiran I.

3. Anonim. (1998b). Keputusan Menteri Negara Lingkungan Hidup No. 3 Tahun1998 Tentang : Baku Mutu Limbah Cair Bagi Kawasan Industri, Republik Indonesia, Lampiran II. 
4. Anonim. (2001). Peraturan Pemerintah No. 82 Tanggal 14 Desember 2001 Tentang : Pengelolaan Kualitas Air dan Pengendalian Pencemaran Air, Kriteria Mutu Air Berdasarkan Kelas, Republik Indonesia, Lampiran.

5. Anonim. (2003). Keputusan Menteri Negara Lingkungan Hidup No. 112 Tanggal 10 Juli 2003 Tentang : Baku Mutu Limbah Domestik, Republik Indonesia, Lampiran.

6. Anonim. (2005). Laporan Pemantauan Kualitas Air Sungai Sasaran Prokasih 2005, Badan Pengendalian Dampak Lingkungan Daerah (BAPEDALDA), Provinsi Daerah Istimewa Yogyakarta.

7. Anonim. (2006). Laporan Pemantauan Kualitas Air Sungai Prokasih Tahun 2006, Badan Pengendalian Dampak Lingkungan Daerah (BAPEDALDA), Provinsi Daerah Istimewa Yogyakarta.

8. Anonim. (2007). Peraturan Gubernur Daerah Istimewa Yogyakarta No. 21 Tahun 2007 Tentang : Penetapan Kelas Air Sungai di Provinsi Daerah Istimewa Yogyakarta, Provinsi Daerah Istimewa Yogyakarta.

9. Feybe, E.N.L. (2006). Hak Atas Akses Sumber Daya Air Bagi Masyarakat di Jogjakarta, Sekretariat Kelompok Kerja (POKJA) Air Minum dan Penyehatan Lingkungan (AMPL), Jakarta.

10. Fiona, R. (2006). Limbah Domestik, Pencemaran Air \& Eksploitasi Air Tanah, Tekno Limbah Majalah Pusat Teknologi Limbah Cair, vol. 1, hal. 12 - 15. http://www.ampl.or.id/detail/detail01.php?row=1\&tp=artikel\&ktg=airmi. Akses 21 Februari 2007.

11. Pieter, L. (2007). Yogyakata, Kota Berhati Nyaman, Tekno Limbah Majalah Pusat Teknologi Limbah Cair , vol. 2, hal. $4-11$. 